Momordicae on $M$. cordifolia in Natal

(6) Aecidium Momordicae on Momordica in Brazil.

The Puccinia upon Melothria pendula is different in shape, color, and size of spores from $P$. Cucumeris and from $P$. Momordicae, and seems clearly to be an undescribed species. The germination of the teleuto-spores occurs freely in the older sori, placing the rust among the Leptopucciniae. The following description is proposed.

Puccinia Melothriae, n. sp. - III. Teleutosori: hypophyllous, crowded in irregular concentric circles, pustular, soon naked, pulverulent, cinnamon-colored (no. 32 Sacc.), cinereous on germination, ruptured epidermis inconspicuous; spots pale, indefinite. Teleutospores: hyaline to straw-colored (no. 26 Sacc.), $40-5^{2} \times$ ıо-ı6 $\mu$; slightly or not at all thickened at apex, often not constricted at septum, wall about $2 \mu$ thick, smooth. Terminal
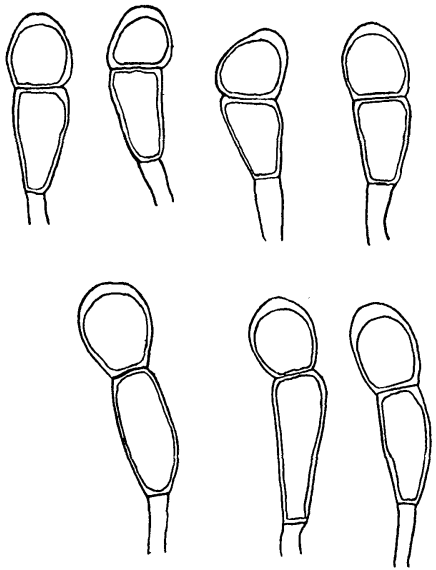

Puccinia Melothriae, n. sp. cell usually round, rarely oblong, го- $6 \times \mathrm{I} 2-20$. Basal cell wedgeshaped, IO-I $5 \times 20-30 \mu$. Pedicil $20-45 \mu$ long, hyaline. Germination immediate; that of the terminal cell by an apical promycelium, that of the basal cell by a lateral promycelium.

On Melothria pendula L., West Raleigh, N. C., 9-15-06, F. L. Stevens and J. G. Hall, type no. 47I.-F. L. Stevens, West Raleigh, N.C.

\title{
AN INSTANCE OF MUTATION
}

Euphorbia marginata Pursh, commonly called in Colorado "snow-onthe-mountain," is easily recognized by its white-margined upper leaves or bracts, and the five white appendages of the floral glands. In the splitting up of the old genus Euphorbia, it has been referred to a genus Dichrophyllum Kl. \& Garcke, and distinguished from Tithymalus Adans by the characters just mentioned. In Tithymalus there are but four glands, with rudiments of the fifth. All authors seem to agree that $E$. marginala has five glands; "three" in BRITTON and BRown, Ill. Flora 2:376, is a mere misprint, as the figure shows. Having recently had occasion to examine E. marginata at Boulder, Colorado, I have been astonished to find that four glands is normal in this locality, and a plant with five glands 
has not been seen. One large plant deviated still more, showing mostly three glands, and the white margins of the leaves very narrow. I wrote to Professor Aven Nelson about this, and he replies "all Colorado specimens do not show the reduction in number which you mention, and some of the specimens are quite devoid of white on the margins of many of the leaves." We seem to have a clear case in which a new race has been formed by mutation, or more precisely the meristic variation of BATESON. Incidentally it seems fairly evident that the genus Dichrophyllum cannot be maintained; so we have:

Tithymalus marginatus (Euphorbia marginata Pursh, 1814);

T. marginatus tetramerus, var. nov., the Boulder race with four glands.T. D. A. Cockerell, University of Colorado, Boulder. 